Research paper

\title{
Distribution and population density of the Russian desman (Desmana moschata L., Talpidae, Insectivora) in the Middle Volga of Russia
}

\section{Alexey Andreychev*, Vyacheslav Kuznetsov and Alexandr Lapshin}

\begin{abstract}
Andreychev, A., Kuznetsov, V., Lapshin, A. 2019. Distribution and population density of the Russian desman (Desmana moschata L., Talpidae, Insectivora) in the Middle Volga of Russia. Forestry Studies | Metsanduslikud Uurimused 71, 48-68, ISSN 1406-9954. Journal homepage: http://mi.emu.ee/forestry.studies
\end{abstract}

\begin{abstract}
To date according to the registration work, the number of the Russian desman determined actually is 588 individuals in Mordovia. Based on extrapolation, the total desman population in Mordovia is about 1,400 individuals. We may assume that the most of the desman population is concentrated on floodplain lakes and reclamation canals. The highest density of the desman population in Mordovia was recorded in Krasnoslobodsky and Temnikovsky Districts ( 10.5 and 8.2 burrows per $\mathrm{km}$, respectively). About 400 animals may live on the shore of the rivers Vad, Partsa, Yavas, Vindrey, Nuluy, and Kundybolka. The mean value of density of the desman population on the rivers was 0.9 burrows per $\mathrm{km}$ of the coastline, which corresponded to habitat quality class IV (0.5-5 burrows per $\mathrm{km})$. The distribution of habitats across river basins is extremely uneven. The main part of the desman population is restricted to the Moksha basin (more than 1,350 individuals), and in the Alatyr basin (left tributary of the Sura River) just twenty individuals were recorded.
\end{abstract}

Key words: Red Data Book, desman, burrow, number of individuals, river, lake, Mordovia.

Authors' addresses: Department of Zoology, Mordovian State University, Bolshevistskaya str. 68, 430005, Saransk, Republic of Mordovia, Russia; *e-mail: andreychev1@rambler.ru

\section{Introduction}

The Russian desman Desmana moschata (L.) is in the Red List of the International Union for Conservation of Nature (Kennerley \& Turvey, 2016; Rutovskaya et al., 2017b), the Red Data Book (2001) of the Russian Federation, Appendix II of the Bern Convention, and Red Data Books of Russian regions, including the Red Data Book (2005) of Mordovia. The study of the Russian desman in the Republic of Mordovia was initiated by well-known mammalogist L.P. Borodin. In his monograph and articles L.P. Borodin stated the following habitat areas of the desman within the territory of Mordovia: Zubovo-Polyansky, Temnikovsky, Tengushevsky, Kochkurovsky, Bolshebereznikovsky, and Dubensky Districts (Borodin, 1963, 1970). He noted that the desman was registered in the Sura, Moksha, Vad, Vysha, Yuzga, Partsa Rivers and their tributaries. 
L.P. Borodin stated that there had been natural population of the species in the territory of Mordovia for a long time, which was only to some extent supported by reintroducing the animals in the 1930s. In October 1937, 98 animals (46 males and 52 females) were brought to lakes Inorka and Valza in the Mordovsky Nature Reserve from Kadomsky District of Ryazan Region, that is, from the lower Moksha floodplain. On September 10, 1938, another 97 animals were brought from Kadomsky District and released into Inorka, Tarmenka, and Taratino lakes (Borodina et al., 1970).

Basins of the rivers Moksha and Sura are in the desman range. According to the literature dating back to the first half of the $20^{\text {th }}$ century, in the Moksha basin the desman was common along the Moksha, starting from the Kovylkino station and up to the river mouth, along the Partsa River with tributaries and on the Vysha River near the village of Kirillovo (Kufeld, 1939; Borodin, 1963). According to the data for 1954, the desman in Mordovia was spread along the Moksha from the town of Temnikov (Temnikovsky District) to the village of Norovatovo (Tengushevsky District) and along the Vad with its tributary Partsa within the borders of Zubovo-Polyansky District. In the second half of the 1940s, I.S. Tereshkin witnessed repeated desman captures on the Yuzga River (the Moksha tributary) below the road to the village of Tengushevo. The desman also got into fishing creels on the branch connecting the large forest lake Piyavskoe (near the village of Ivanovka, Tengushevsky District) with the Yuzga riverbed. In 1950, a pond was built near the village of Aleksandrovka on the small river Vyazhga, which joins the Moksha down the village of Narovatovo (Tengushevsky District). In 1953, I.S. Tereshkin caught a desman with a dragnet in this pond. All the literary facts mentioned above for the Moksha and its tributaries confirm a rather widespread desman distribution in this river basin, and thus indicate the longlived habitat of the animal.
In the past, the Sura basin was part of the area of the Russian desman. According to M.N. Bogdanov (1871), the desman was numerous in the Sura valley up to Penza. B.M. Zhitkov (1898) notes that the desman was especially abundant in the middle reach of the Sura, and along the Alatyr and Pyana it lived only near the mouths of these rivers. In 1925-1928, the desman lived throughout the floodplain of the Sura (Paramonov, 1928). It was also noted that the desman was common in many areas along the Sura, and along the Alatyr it was found in the lower reaches near the river mouth (Anonymus, 1936). According to N.S. Kufeld (1939), the desman was numerous in the upper flow of the Sura to Inzensky District of Penza Region. In lower areas within the borders of Mordovia, the desman was seen occasionally near the villages of Sabaevo and Permisi and farther from Bolshiye Berezniki village to the Alatyr River. Along the Alatyr, the desman was common from the mouth to the borders of Ichalkovsky District of Mordovia (Borodin, 1963; Tereshkin, 1971). According to L.P. Borodin, until 1966 the desman was found in the floodplain of the Sura in Kochkurovsky, Bolshebereznikovsky and Dubensky Districts. In 1953-1956, desmans were captured in Kochkurovsky and Bolshebereznikovsky Districts, where 56 and 68 individuals were caught, respectively. The desman was seen in Dubensky District of Mordovia, but there was no hunting arranged (Borodin, 1970).

In 1961, L.P. Borodin and I.S. Tereshkin set up three stations to study the desman (two in the Moksha River floodplain, and one in the Sura River floodplain) (Borodin, 1963; Tereshkin, 1971). The first station was laid in the Moksha floodplain between the town of Temnikov and the village of Stary Gorod. The floodplain width in the observation area reached $5 \mathrm{~km}$ in diameter. The floodplain is right-sided, mostly open, with a large number of lakes. Many of them had a muddy bottom. Ten lakes (Shirchek, Bobrovoe, Ogorodnoe, Vatazhnoe, Cher- 
nomutskoe, Starica, Nemcovo, Krasnenkoe, Linevo, Olyushka) with a total coastline length of $8 \mathrm{~km}$ were chosen as references. Over the years of observation, the average number of desman burrows per coastline kilometer varied from 2.9 to 4.1 .

The second station was set up in the Moksha floodplain within the territory of the Mordovsky Nature Reserve. The width of the floodplain in this area reached $4 \mathrm{~km}$ in diameter. The floodplain is two-sided. Nine lakes (Kuniha, Gorbatenkoe, Korlyshki, Krapivnoe, Chernenkoe, Chernye Luzhki I, Chernye Luzhki II, Chernye Luzhki III, Dikaya) with a total coastline length of $8 \mathrm{~km}$ were chosen as references.

The third station was set up in the Sury floodplain to the east of the village of Permisi, to the south of Lake Inerka, Bolshebereznikovsky District. The station lakes were located within Bolshebereznikovsky and Kochkurovsky Districts. Ten lakes (Pendelyukha, Chudomaz, Sarazerka, Bukach, Bulyk, Kriusha krestovaya, Shirokoe bolotnoe, Dolgenkoe, Kriusha Arapovskaya, Bezymyannoe) with a total coastline length of $8 \mathrm{~km}$ were chosen as references (Borodin, 1970). In 1968, I.S. Tereshkin registered 4.7 desman burrows per coastline $\mathrm{km}$ at the reference station in the Sura floodplain (Tereshkin, 1971).

In addition to the three stations set up by L.P. Borodin, there is another desman station in Mordovia. It was set up by N.K. Shidlovskaya in Tengushevsky District in 1961 and named "Krasny Yar". It was located in the vicinity of Krasny Yar, Staraya Kocheevka, and Vedenyapino villages. This station was located $35-40 \mathrm{~km}$ from the Mordovsky Nature Reserve. In 1961, 19 lakes were surveyed, 9 (Obshirki, Mochilki, Zaresheno, Melkoe, Uksala, Ovechiy Poldnik, Muromka, Bolshoe Rassoshnoe, Maloe Rassoshnoe) of which were included in a control and registration point. The total coastline length of these lakes was 12 $\mathrm{km}$. A total of 38 desman burrows were found on these lakes in the fall of 1961, which corresponded to 42 individuals
(Shidlovskaya, 2018). According to these results, the average population density in the station was 3.5 individuals per coastline $\mathrm{km}$ or 3.2 burrows per coastline $\mathrm{km}$. In view of the value of the results obtained for this station, the distribution of burrow densities over specific lakes should be made since the variation is significant. For example, the density at Lake Zaresheno was 0.33 burrows per $\mathrm{km}$, and at Mochilki and Ovechiy Poldnik lakes it was 22.5 burrows per $\mathrm{km}$ and 30 burrows per $\mathrm{km}$, respectively. Moreover, the report provides information about banding of the desman on non-station lakes, namely the Telimerka, Baklusha, and Uzhovo lakes.

In 1982, V.S. Vechkanov, Head of the Zoology Department, V.M. Smirnov, Head of the Zoology Department Laboratory, and a group of students A.A. Ananyev, A.V. Shevorakov, V.M. Matyaev, Yu.A. Tomilov, G.F. Grishutkin, S.A. Mikova performed registration work on 163 lakes of Mordovia. According to the survey and registration results, scientists noted the desman's dwelling in water reservoirs of six districts: Zubovo-Polyansky, Krasnoslobodsky, Elnikovsky, Temnikovsky, Ardatovsky, Kochkurovsky (Report, 1982). The results of the surveys revealed 5.25 burrows per coastline $\mathrm{km}$ along the $\mathrm{Vad}$ from the mouth of the Yavas near the village of Ozyorny to the mouth of the Tast, 1.5 burrows per $\mathrm{km}$ along the Moksha in the protected area of the Mordovsky Nature Reserve, 2.1 burrows per $\mathrm{km}$ along the Alatyr from the village of Anyutino downstream to the village of Redkodubiye, and 2.8 burrows per $\mathrm{km}$ along the Sura in Kochkurovsky District. The authors noted that the desman's settlement in Kochkurovsky District was the most southerly point in the Sura floodplain within the borders of Mordovia. The desman was not registered on the territory of Bolshebereznikovsky and Dubensky Districts. In 1982, according to the extrapolation made, the total desman number in Mordovia was one thousand individuals. In fact, 149 desman indi- 
viduals were registered in lake burrows, 64 of which were documented in Zubovo-Polyansky District (Staryy Vad, Krugloe, Mokshayevo, Siyarka, Popovskoye, Narehrke, Lokseyevo, Kondraehrke, Utinoe lakes), 42 - in Kochkurovsky District (Malyy Kamysh, Maloye Martianovo, Bolshoye Martianovo, Selevyarka, Stychnoye, Cherepashnoye, Bolshoy Kamysh, Bolshoy Chadamas, Cheremukha, Poperechnoye lakes), 25 - in Ardatovsky District (Kochalino, Terlyaka, Egadam, Mukorka, Kamyshovoe, Glubokoye, Bolotnoye, Seske lakes), and 18 - in Temnikovsky District (Kanal, Krasnenkoe, Linevo, Lipovoe, Rubezhnoe, Starica lakes).

In 1983, V.S. Vechkanov et al. carried out research on introducing the desman into two floodplain lakes Dolgoye and Krugloye on the territory of the biological station of the Mordovian University in Bolshebereznikovsky District. In total, ten desmans captured on the Staryy Vad and Utinoe lakes in Zubovo-Polyansky District were released. 5 desmans were released on the lake of Dolgoye. 5 desmans were released on the lake of Krugloe. According to the report, no desmans were observed during registration in Kochkurovsky and Elnikovsky Districts (Report, 1983).

In the autumn of 2001, the republic's hunting administration performed work in six districts, including in the Moksha basin within the territory of Temnikovsky and Krasnoslobodsky Districts. The abundance of the desman was 2.7 and 0.6 burrows per $\mathrm{km}$, respectively. The extrapolation of the data performed by G.V. Khakhin to all floodplain lands revealed that the species stock in Mordovia was about 500 animals (Khakhin, 2009), with the estimated number of desmans in the Moksha floodplain within the borders of Mordovia equal to 250 individuals (Onufrenya \& Onufrenya, 2016).

Considerable time has passed since L.P. Borodin's active study of the Russian desman in the republic, but there were practically no studies on the habitats and registration of the desman population for that period. Only oral reports on desmans' habitats from state hunting inspection specialists and foresters were received. Therefore, we used the following two control dates to estimate the distribution of the Russian desman within the territory of Mordovia in the past: 1) the period of L.P. Borodin's studies before 1970, and 2) the period of two-year registration work by V.S. Vechkanov and others (Report, 1982, 1983). The latest report on the desman in Mordovia was not available to a wide range of scientists who studied the desman. Therefore, the subsequent publications contained information on the desman in Mordovia borrowed by other authors from the available works of L.P. Borodin, in particular for the years of 1963 and 1970. V.S. Vechkanov's data were included in the monograph of G.V. Khakhin \& A.A. Ivanov (1990); however, 1985 was indicated there, and the registration work was carried out in 1982. This situation with typing errors in the literature, lack of data and, in general, termination of the study of the desman was typical not only of Mordovia, but also of other regions of Russia. As a result, A.S. Onufrenya and M.V. Onufrenya reported the reliable presence of the species only in 6 specially protected natural areas of Russia in 2007, and, notably, the Mordovsky Nature Reserve was not included (Onufrenya \& Onufrenya, 2008a). At one time, 4 desmans in specially protected natural areas were organized on the territory of the former USSR: Oka Nature Reserve, Khopyor Nature Reserve, Mordovsky Nature Reserve, and Klyazminsky Nature Reserve. The Klyazminsky Nature Reserve closed. The Oka Nature Reserve and Khopyor Nature Reserve are among these 6 specially protected natural areas in desman territories.

Our research on the desman in Mordovia has been conducted since 2009. First of all, at the initial stage of research, we extradited the spread of the species and the state of the population. The purpose of the presented work is the analysis of the 
past and modern distribution of the Russian desman. The data was obtained by us for over 10 years (2009-2018). The results of our work had been collected for a long time. The data were not published until completion of research. Only brief summaries were published in the collections of the regional Red Book (Andreychev et al., 2009, 2010, 2012, 2014).

\section{Material and Methods}

The Republic of Mordovia is located in the centre of the European part of Russia. Its extreme points are defined by geographical coordinates $42^{\circ} 11^{\prime}-46^{\circ} 45^{\prime}$ E and $53^{\circ} 38^{\prime}$ - $55^{\circ} 11^{\prime} \mathrm{N}$ (Figure 1). The maximum distance from west to east is $298 \mathrm{~km}$ and the distance from north to south is 57 to 140 $\mathrm{km}$. The area of the republic is 26.2 thousands $\mathrm{km}^{2}$. Features of the geological structure of Mordovia are determined by its location in the central part of the Russian Platform and the north-western slopes of the Volga Upland. In the western part of the Republic of Mordovia, the Volga Upland reaches the Oka-Don Lowlands.

The climate of the region is moderately continental with pronounced seasons throughout the year. The influx of direct solar radiation in Mordovia varies from 5.0 in December to $58.6 \mathrm{~kJ} / \mathrm{cm}^{2}$ in June. The total radiation throughout the year is 363.8 $\mathrm{kJ} / \mathrm{cm}^{2}$; the radiation balance is $92.1 \mathrm{~kJ} /$ $\mathrm{cm}^{2}$. The average annual air temperature varies from 3.5 to $4.0^{\circ} \mathrm{C}$. The average temperature of the coldest month (January) is in the range of $-11.5 \ldots-12.3{ }^{\circ} \mathrm{C}$. Temperature drops down to $-47^{\circ} \mathrm{C}$ occur. The average temperature of the warmest month, i.e. July, is in the range of $+18.9 \ldots+19.8^{\circ} \mathrm{C}$. Extreme temperatures in the summer reach 37 ${ }^{\circ} \mathrm{C}$. The average annual precipitation in the territory of Mordovia is $480 \mathrm{~mm}$. Over the course of observation lasting many years, periods of high and low humidity were noted, ranging between the minimum and maximum values of $120-180 \mathrm{~mm}$. Distri- bution of precipitation across the territory is not very diverse. The average long-term value of evaporation is calculated to be in the range of 390-460 $\mathrm{mm}$.

Mordovia is located in the south-western part of the Volga River basin. $47 \%$ of the area is located in the basin of Sura and $53 \%$ in the basin of Moksha. Moksha is the main river in western Mordovia that flows in the meridional direction to the confluence of the Urkat River, where its direction changes to the sublatitudinal. The Moksha is the right tributary of the Oka River and empties into it. The channel is $60-90$ $\mathrm{m}$ wide and 5-8 $\mathrm{m}$ deep. The absolute water level is $89-126 \mathrm{~m}$. The Moksha's largest tributaries in the territory of Mordovia are the Vad, the Satis, the Urkat, the Sivin, and the Issa.

The Sura River flows along the southeastern border of Mordovia. The width of the channel varies from 100 to $150 \mathrm{~m}$ and its depth is $10 \mathrm{~m}$. It flows $0.3-1.0 \mathrm{~m} / \mathrm{s}$ and its absolute water level is $90-115 \mathrm{~m}$. The largest tributaries of the Sura include the Bolshaya Ksha, the Bolshaya Sarka, the Piana, the Menya, and the Alatyr.

The density of the river network in the entire area is $0.23 \mathrm{~km}$ of river per $\mathrm{km}^{2}$. By the nature of intra-flow distribution, the republic's rivers are of Eastern European type. The water regime of the rivers is characterized by the presence of summer and winter seasons, spring floods and autumn floods. The most high-water month is April. $3-15 \%$ of the annual runoff occurs during the low-flow period. The river length is used in the study as a criterion for classifying rivers. We validate this method because most reference books on surface water resources are based on that classification (Sokolov, 1964; Sokolovsky, 1968; Yevstigneyev, 1990; Chalov, 1994). According to the classification, large rivers are rivers the length of which varies from 301 to 1,000 km. Medium rivers extend from 101 to $300 \mathrm{~km}$. The length of small rivers ranges from 26 to $100 \mathrm{~km}$. The smallest rivers are usually rivers with a length of up to 
$25 \mathrm{~km}$. In the territory of Mordovia, there are about 1,520 watercourses with the total length of $9,250 \mathrm{~km}$. The major share (96\%) of the river network of the republic falls on the smallest rivers. These constitute $65 \%$ of the total length of all rivers. Small rivers make up $4 \%$ of the total and $22 \%$ of the length of all rivers. The share of medium-sized rivers (the Issa, the Sivin, the Insar, the Partsa, the Vad, the Visha, and the Alatyr) in the total length is negligible $(0.5 \%)$. Two rivers - the Moksha and the Sura - are more than $500 \mathrm{~km}$ long (Water resources, 1999). Small rivers and streams are distributed unevenly in the basins of large rivers. In the river Sura, there are 24 small rivers and 286 very small rivers and streams. 30 small rivers and 385 very small rivers and streams flow into the Moksha River.

It is typical of small rivers to have a 5 to $10 \mathrm{~m}$ wide channel, with extensions up to $35 \mathrm{~m}$; for average rivers, from 25 to 50 $\mathrm{m}$ with extensions up to $70 \mathrm{~m}$. Large rivers are 100 to $150 \mathrm{~m}$ wide and in the mouths, $300 \mathrm{~m}$. Rivers are shallow and the prevailing depths of small rivers are 0.4 to $1.2 \mathrm{~m}$, for average ones 1.5 to 2.0, and for large ones 2.5 to $3.5 \mathrm{~m}$. In rundowns, the depth throughout is less than $0.5 \mathrm{~m}$. The flow rate varies from $0.2 \mathrm{~m} / \mathrm{s}$ to $1.2 \mathrm{~m} / \mathrm{s}$ in rundowns (Water resources, 1999).

There are approximately 500 lakes in Mordovia, five of which are large, and the rest are medium- or small-sized. Almost all lakes are floodplain, located in the valleys of the main rivers of the region being typical habitats of the desman.

Surveys of possible habitats of the Russian desman in the areas of the Republic of Mordovia have been conducted. Traditional guidelines on the study of the desman were used and taken into account during the research (Kudryashov, 1976; Khakhin \& Ivanov, 1990; Marchenko, 2011). The desman survey was carried out mainly by calculating the inhabited desman burrows (Kudryashov, 1976; Onufrenya \& Onufrenya, 2016). Surveys were carried out during daylight hours by going through the coastline of water bodies overland along the water edge on foot or by boat. At least $70 \%$ of the examined reservoirs were covered by the survey. Surveys were conducted in different areas over different years from 2009 to 2018. We did not identify any stationary water bodies, but on some lakes the repeated surveys were carried out several years later. First of all, our task was to cover the largest possible area to determine the distribution and population density of the Russian desman in Mordovia.

The total number of desmans was calculated by extrapolating the surveyed data over the entire territory using the following formula:

$$
X=K \frac{L n m}{100 L_{1}}
$$

where $X=$ the absolute desman population size, $K=$ the conversion factor (average number of animals per burrow), $L=$ the length of the coastline of all reservoirs in the area; $n=$ the number of shelters counted during the survey; $m=$ the length of the control coastline expressed as a percentage compared to that measured on the map; $L_{\mathrm{I}}$ $=$ the length of the surveyed coastline.

In areas inhabited by the desman only, the conversion factor had the following values: September - 1.86; October (before freeze-up) - 1.10, and October-November (clear ice period) - 0.68. In areas inhabited by both desmans and muskrats, conversion factors were calculated for September-October (before freeze-up): 0.6 for desmans, and 1.0 for muskrats (Kudryashov, 1976; Onufrenya \& Onufrenya, 2016). The habitat quality of lands was traditionally determined by the population density of the desman as follows: quality I - > 25 burrows per $\mathrm{km}$, quality II -15 to 24 burrows per $\mathrm{km}$, quality III - 6 to 14 burrows per $\mathrm{km}$, quality IV -0.5 to 5 burrows per $\mathrm{km}$, and quality $\mathrm{V}-<0.5$ burrows per $\mathrm{km}$. 


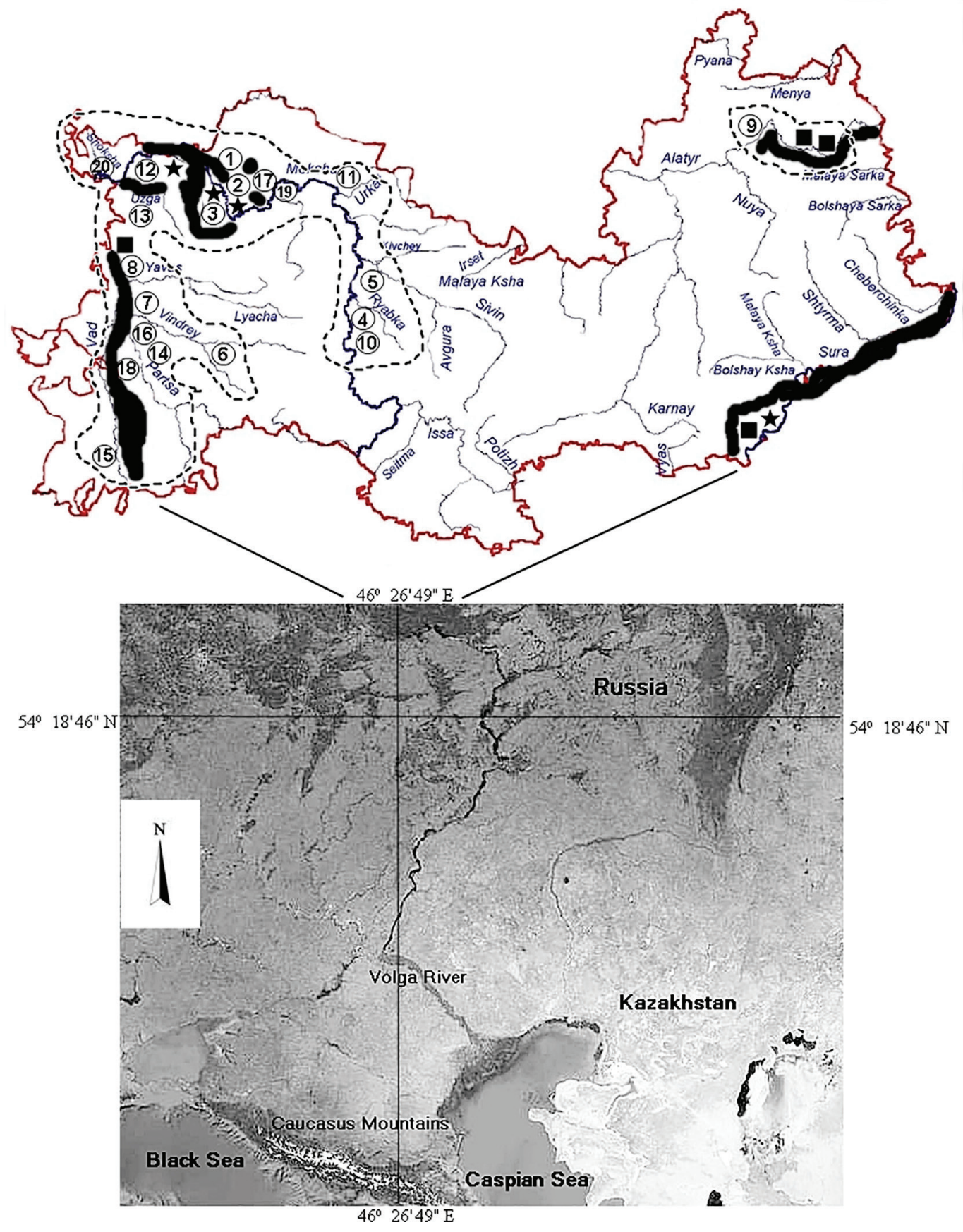

Figure 1. Past and present distribution of the Russian desman in Mordovia. Note: the dotted line indicates the current range of the species within the region, the black fill indicates the distribution area until 1970 (Borodin 1963, 1970). $\star$ - Stationary observation points for desmans set up by L.P. Borodin (1970); I.S. Tereshkin (1971); N.K. Shidlovskaya (2018). - - Desman registration points in 1982 (Report, 1982) (1) to (20) - Desman registration points according to the results of this research; the point numbering is given in the Table 1. 


\section{Results}

Altogether, 174 desman burrows were found in the reservoirs surveyed. The abundance was 1.6 burrows per coastline $\mathrm{km}$. The conversion factors and the total coastline length of the reservoirs where the research was carried out let us conclude that at least 588 individuals inhabited the surveyed territory. It should be noted that in this calculation we were dealing with the minimum population size of the species since only desman burrows were taken into account. Considering the fact that the reservoirs where the desman's presence was detected also had beaver's burrows in most cases, the desman numbers will be much larger since the desman probably uses beavers' shelters, as well. However, in this work we did not take this circumstance into account, and considered only desman burrows. In addition, the situation in the western Mordovia consists in the fact that there are no traces of the muskrat registered on many lakes. Therefore, it is logical to use higher conversion factors, September - 1.86; October (before freezeup) - 1.10, and October-November (clear ice period) -0.68 .

To assess the total desman stock in the water bodies of Mordovia, we carried out an analysis of water bodies habitable for the Russian desman using OziExplorer software and satellite images. In this analysis, we considered only those areas in which the desman had been registered. The riverbed coastline was analyzed separately. The riverbeds of the Nuluy $(35.1 \mathrm{~km})$ and Kundybolka $(8.2 \mathrm{~km})$ were studied along the entire length. The riverbeds of the Vad, Partsa, Yavas, and Vindrey were partially studied along $110 \mathrm{~km}$ of the coastline. The mean value for the rivers was 0.9 burrows per coastline $\mathrm{km}$, which corresponded to quality class IV (0.5-5 burrows per $\mathrm{km}$ ). Based on the results obtained, we may assume that about 400 animals live in the above-mentioned rivers.

The distribution of floodplain lakes is given by districts. In Tengushevsky District, 38 lakes are habitable for desmans, with the total coastline length of $60 \mathrm{~km}$ (Figure 2). These lakes have a coastline length of mainly 1 to $2 \mathrm{~km}$. Considering the fact that the mean relative density is 2.4 burrows per $\mathrm{km}$ on the lakes studied in Tengushevsky District, we can assume that 86 to 268 individuals inhabit the lakes in this area. This is due to the fact that according to the results of the work carried out by A.S. Onufrenya \& M.V. Onufrenya (2008b) on the territory of Meschera National Park, not all reservoirs may be inhabited by the desman. This fact was also confirmed by us when different situations were observed on the neighboring lakes: there were both burrows and feeding boards on some lakes, and there were no desman traces on others. In particular, this is characteristic of the Telimerka and Takushevskoe lake margins and reclamation canals near these lakes. The reclamation canal adjacent to Lake Telimerka (south-western part) was found to have desman burrows and some evidence of feeding activity. 130 meters away from the lake on the canal approaching perpendicular to the lake, fresh traces of vital activity of the Russian desman were found. The surveys of reclamation canals to the north and east of the village Standrovo in 2011 did not yield positive results in relation to the desman. The search for traces of desmans' presence on the artificially straightened riverbed of the Yuzga to the east of Standrovo was also unsuccessful. The exploratory research on the reclamation canals to the south of the village Shelubey over the Yuzga revealed the presence of the desman and burrows. In two cases, traces of desman poaching were found with traps from nesting chambers. Excavated beaver burrows were also found on this site. According to local residents, poaching of the Russian desman is common in Tengushevsky District. The survey of the coastline of Lake Beloye located $2.8 \mathrm{~km}$ southeast of the village of Shiromasovo on the Moksha left bank, on 
the border of the Republic of Mordovia and Ryazan Region, did not reveal desman presence. The lake is supposedly of meteorite impact origin; the shores of the reservoir are open, not bushy.

In Krasnoslobodsky District, 25 lakes are habitable for desmans; the total coastline length of these lakes is $30 \mathrm{~km}$ (Figure 3 ). The lakes have a coastline mainly length of less than $1 \mathrm{~km}$. Considering that the mean relative density is 8.9 burrows per $\mathrm{km}$ on the lakes studied in Krasnoslobodsky District, we can assume that 160 individuals inhabit the lakes of this area. In Krasnoslobodsky District, as well as in Tengushevsky District, burrows and feeding boards were often recorded on reclamation canals rather than on the lakes, to which they were adjacent. This situation was common in the vicinity of Nagornoye Shenino and Novaya Karga villages. In general, Krasnoslobodsky District should be recognized as less studied for the desman before we started the work. Perhaps it was of less interest in Borodin's days due to the distance from the Mordovsky Nature Reserve, where L.P. Borodin worked or perhaps also due to fewer lakes in the floodplain. However, the results demonstrate that despite all the circumstances, the territory of the district is of great importance in preserving the desman, since the population density here is the highest. In particular, the highest density of the desman population in Mordovia being 10.5 burrows per coastline $\mathrm{km}$ was registered in 2009 on reclamation canals adjacent to the northeastern part of Lake Churilka.

In Temnikovsky District, 34 lakes are habitable for desmans. The total coastline length of these lakes is $62 \mathrm{~km}$. These lakes mainly have a coastline length of about 2

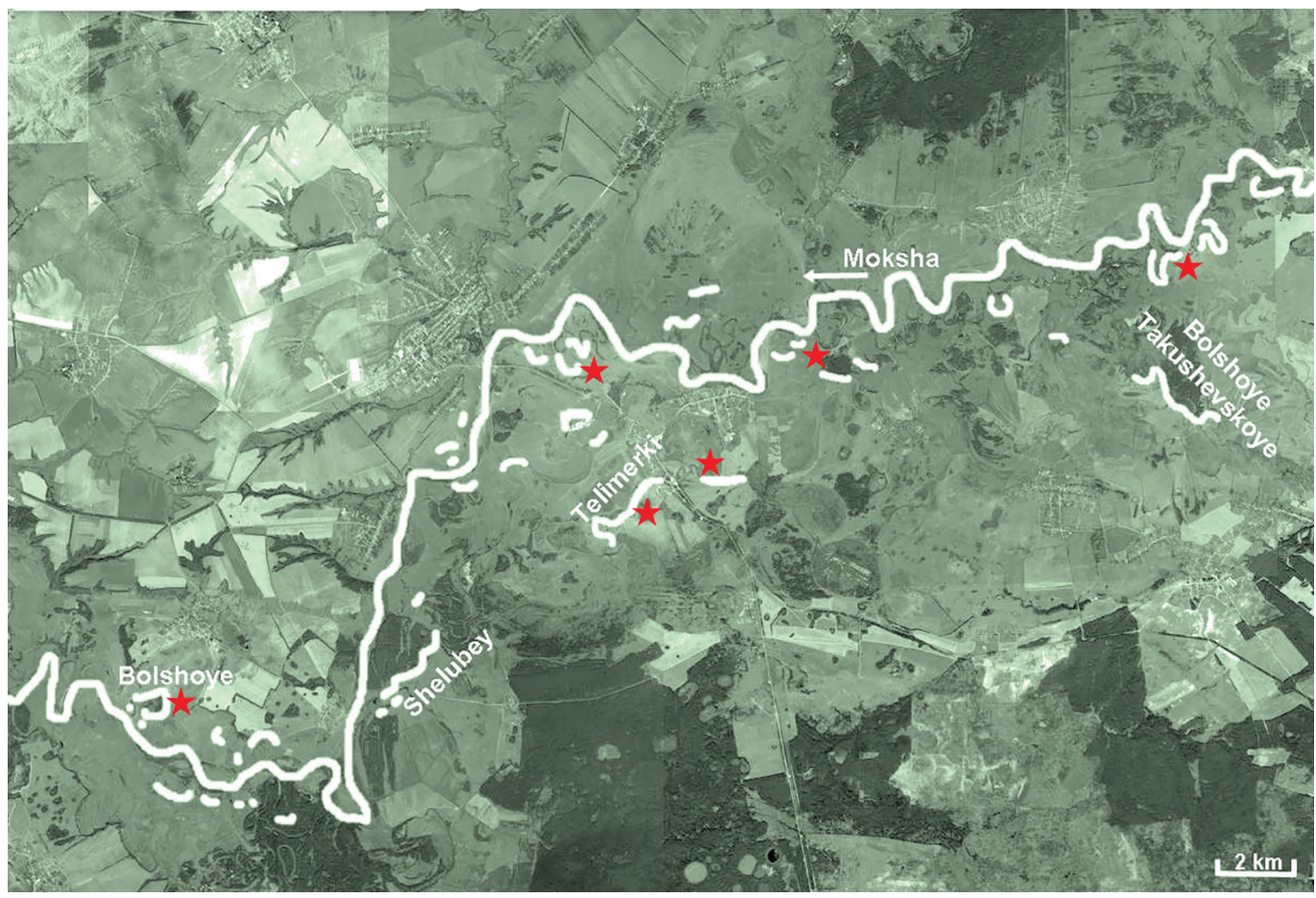

Figure 2. Records of the Russian desman in Tengushevsky District. Note: water bodies are shown in white, $\star$-desman registration points. 


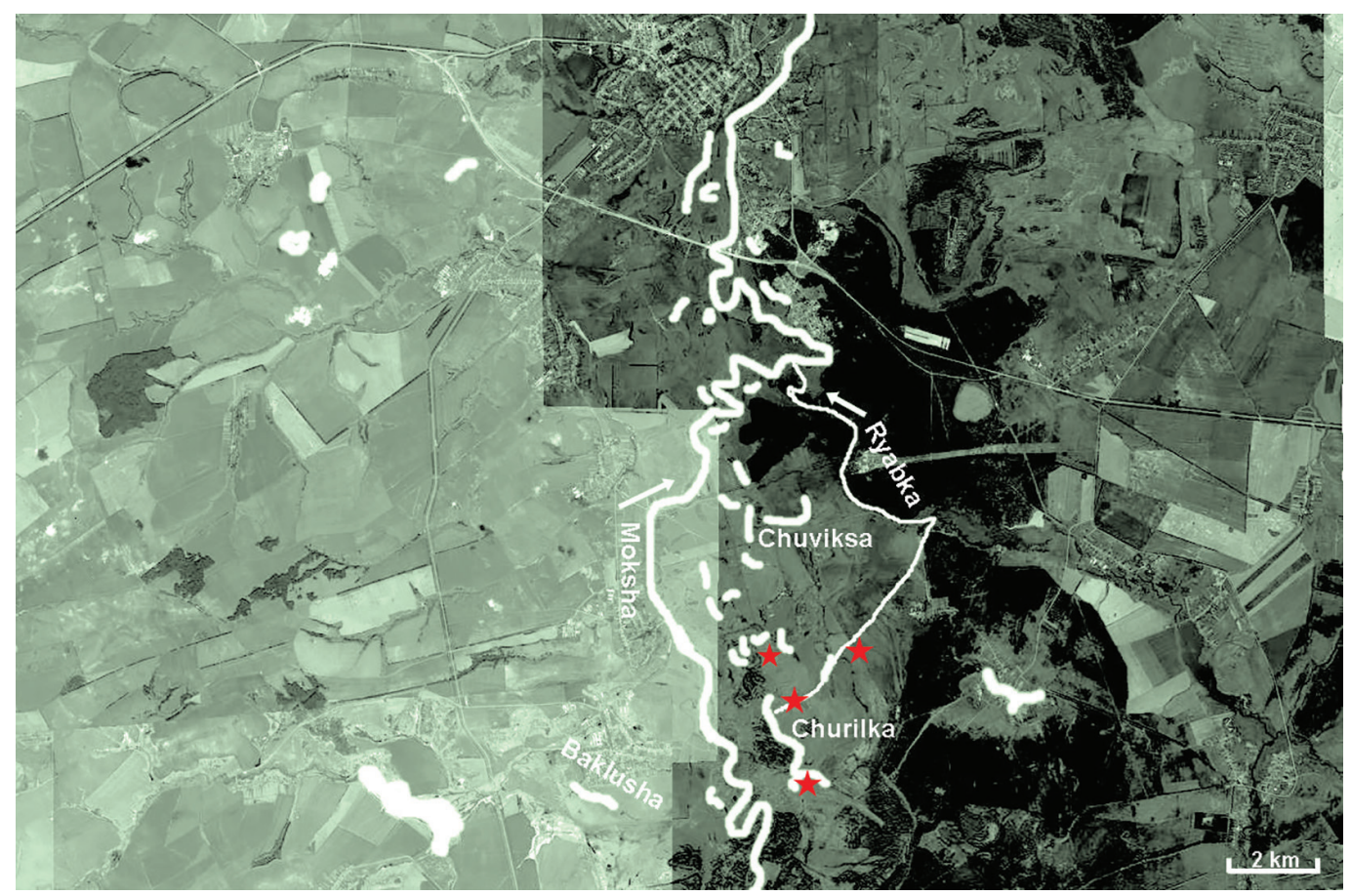

Figure 3. Records of the Russian desman in Krasnoslobodsky District. Note: water bodies are shown in white, $\star$-desman registration points.

$\mathrm{km}$. Considering the fact that the mean relative density is 0.6 burrows per $\mathrm{km}$ on the lakes studied in Temnikovsky District, we can assume that 22 to 69 individuals inhabit the lakes in this area. We started our research on habitats in Temnikovsky District in 2009. According to S.K. Potapov's oral report, he personally watched the desman on Lake Valza. We investigated the eastern part of Lake Valza. No vital activity of the desman was found. The next reservoirs that were surveyed were two ponds near Pushta Settlement. Studies on the entire coastline of the ponds did not give any positive results in relation to the desman. The southwestern part of the coastline of Lake Inorskoye and the coastline of Lake Picherki were investigated. Feeding boards and desman burrows were found on Lake Picherki. According to L.P. Borodin, Lakes Valza and Inorskoye were the main reservoirs in which the desman was released (Borodin, 1963).
Surveys at the first and second station set up by L.P. Borodin were successful (Figure 4,5). The desman was still present in those areas after 57 years of setting the stations up. We surveyed floodplain lakes on the left bank of the Moksha to the west of Temnikov Town (first station). The surveys were started from the mouth part of the Kundybolka where according to N.N. Chuprunov, State Hunting Inspectorate specialist, the desman was previously seen. As a result of the river survey, we also found desman burrows in the European beaver's burrows and passages, which was consistent with the literature data on the symbiotic relationship between the desman and beaver (Barabash-Nikiforov, 1959). High population of the European beaver is favorable for the desman in Mordovia in this respect (Andreychev, 2017). Then we studied the lakes to the north of the Kundybolka mouth. 


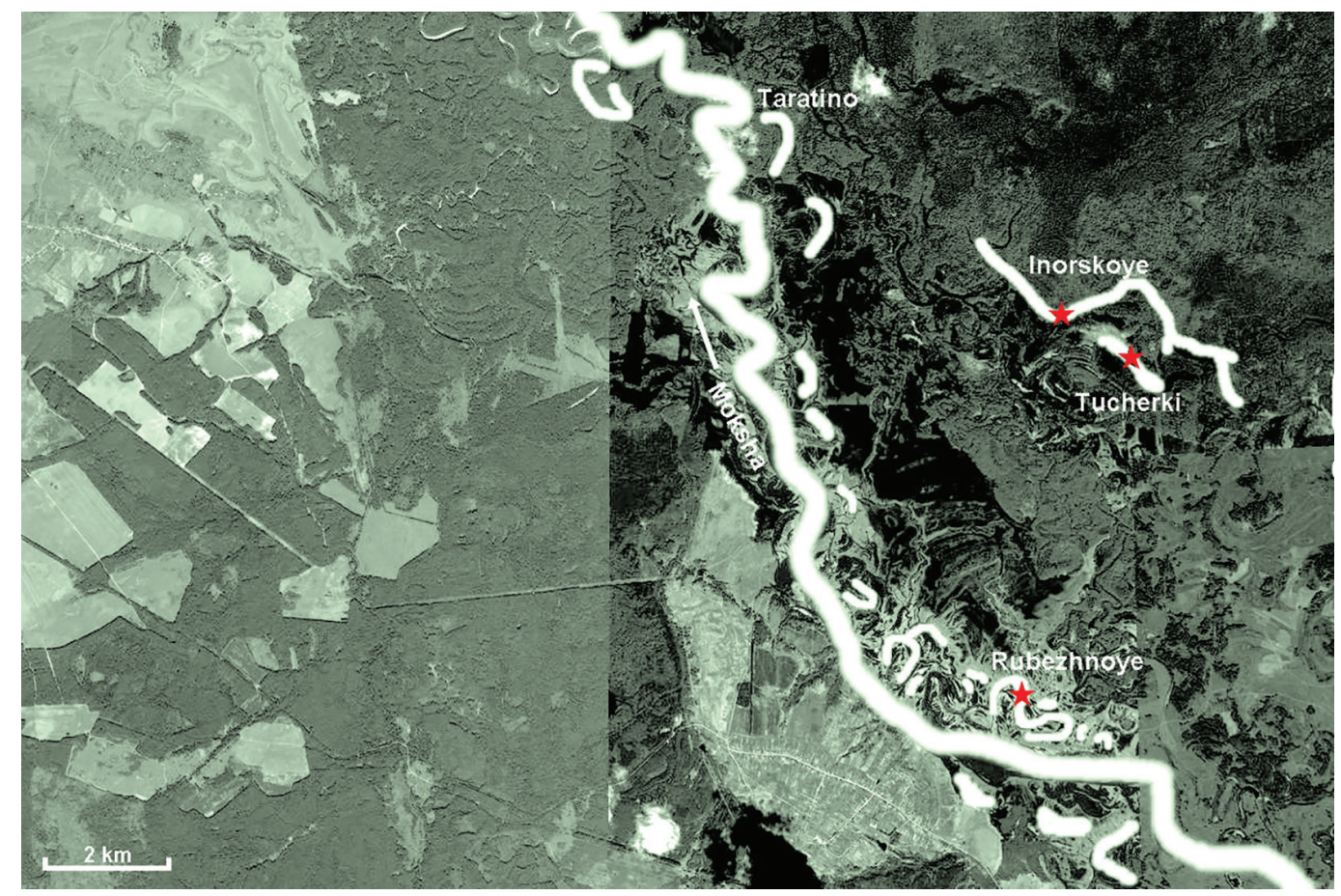

Figure 4. Records of the Russian desman in Temnikovsky District. The first station. Note: water bodies are shown in white, $\star$ - desman registration points.

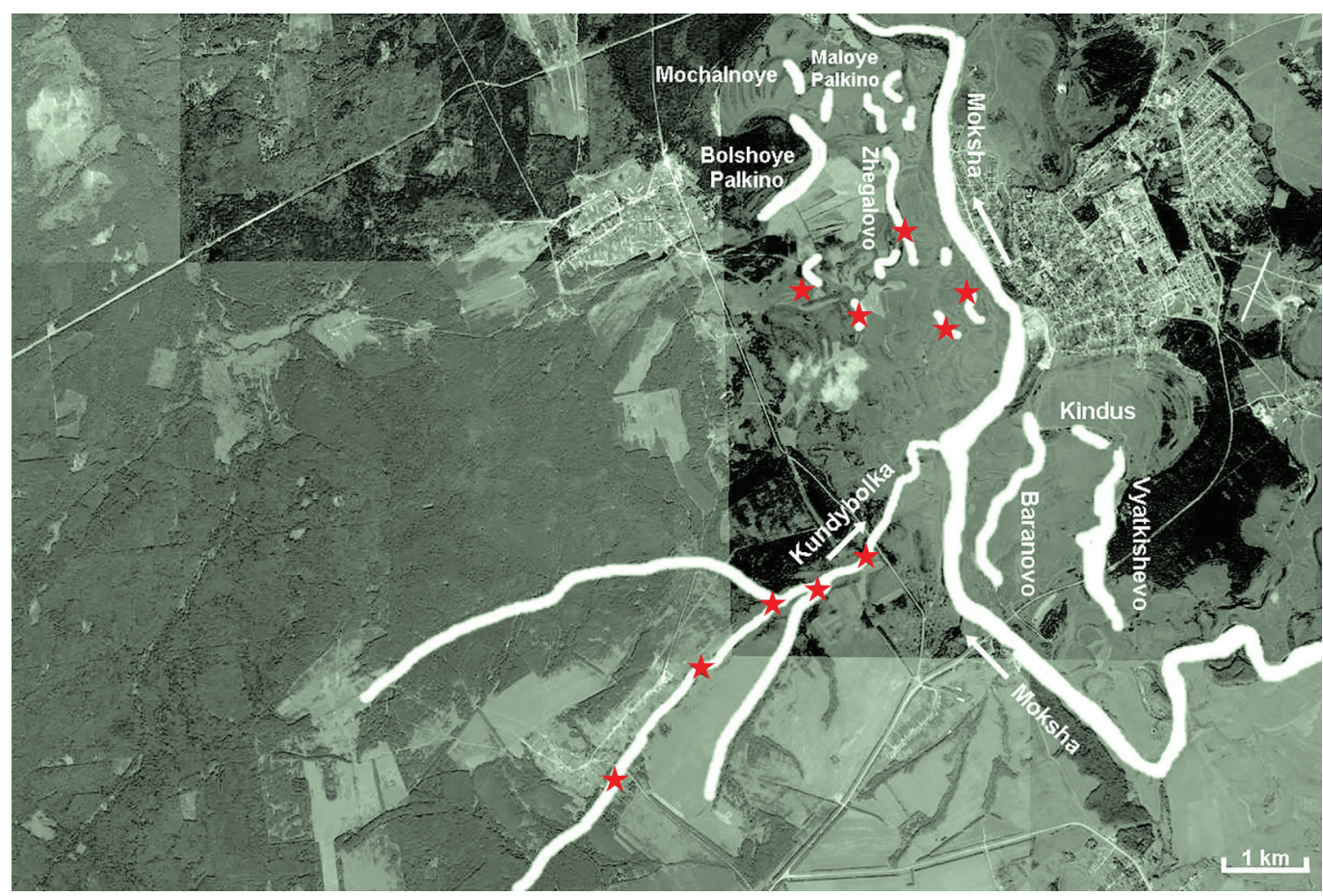

Figure 5. Records of the Russian desman in Temnikovsky District. The second station. Note: water bodies are shown in white, $\star$ - desman registration points. 
The easternmost desman registration points in Temnikovsky District are lakes in the vicinity of Mitryaly and Nizhniye Borki villages. At the latter point in 2017, the desman was registered by E.N. Potapkin (Mordovian Pedagogical Institute) visually and by burrows. Registrations in the eastern parts of Temnikovsky District and the information received from hunting inspectorate specialists in Elnikovsky District suggested a widespread habitat of the species in the Moksha floodplain within the territory of Elnikovsky District. However, our survey of the Nului River in the river mouth showed no evidence of the Russian desman's presence. Earlier in winter 2010, a desman was hunted (shot) by a hunter on this river. This river is swift-flowing, the banks are sandy shale, sloughing shale. Most likely the desman appeared here from the nearest floodplain lakes. The studies carried out by V.S. Vechkanov et al. (Report, 1982) suggest low registration frequency for the desman in the area. All this allows us to classify Elnikovsky District as a low quality $\mathrm{V}$ area.

In Zubovo-Polyansky District, more than 100 lakes are habitable for desmans. The total coastline length of these lakes is $110 \mathrm{~km}$ (Figure 6). These lakes mainly have a coastline length of less than $1 \mathrm{~km}$. Considering the fact that the mean relative density is 2.5 burrows per $\mathrm{km}$ on the lakes studied in Zubovo-Polyansky District, we can assume that 165 to 512 individuals inhabit the lakes in this area. There is a stable desman settlement on Belyye Lakes, which are floodplain water bodies of the Vindrey River. The research revealed burrows and feeding boards of the desman. A large number of burrows and feeding boards were found on the coastal line of the Yavas River from the village of Ozyorny at the mouth of the Vad. It should be mentioned that poaching capture is carried out in the rivers of Zubovo-Polyansky District with the use of fixed nets and other fishing gear. Moreover, we carried out a search for the

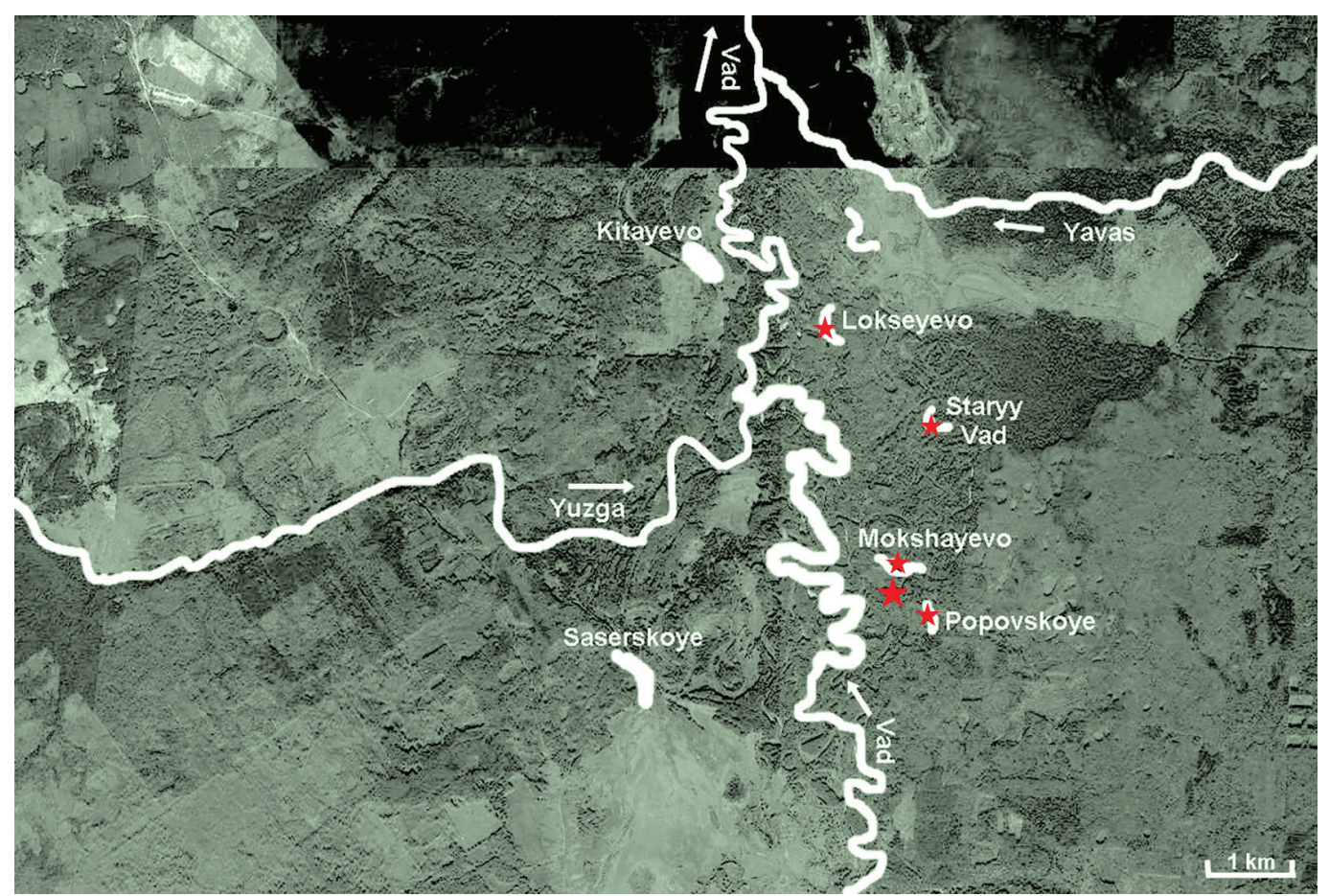

Figure 6. Records of the Russian desman in Zubovo-Polyansky District. Note: water bodies are shown in white, $\star$ - desman registration points. 
desman on the Vysha within the area between the villages of Crimea (Penza Region) and Gorodische. The river banks are steep, thickly grown with vegetation. No signs of the desman were found.

On floodplain lakes of the Vad in the area between the villages of Kiselyovka and Vadovo-Sosnovka, local fishermen rarely observed cases of desman capture. A survey on a part of the Udev River (southern part of Zubovo-Polyansky District) did not give a positive result. The area surveyed represented a meandering section of the river thickly grown with shrubs, and the banks were mostly flat. The floodplain lakes at the time of the survey were covered with aquatic vegetation, no mirror-like surface observed, and the shores were also bushy.

Torbeyevsky District, where the desman was also discovered, adjoins Zubovo-Polyansky district from the east. Habitats were located on floodplain lakes of the rivers Partsa and Vindrey there. Feeding boards and desman burrows were found. Seventy-three gastropod shells were found on one of the feeding boards.

The only area where the desman is currently preserved in the eastern part of Mordovia is Ardatovsky District (the Alatyr basin) (Figure 7). Twenty lakes are habitable for the desman in Ardatovsky District, in the floodplain from the borders of Ichalkovsky District to Redkodubye Village. The total coastline length of these lakes is $47 \mathrm{~km}$. These lakes mainly have a coastline length of about $2 \mathrm{~km}$. Considering the fact that the mean relative density is 0.6 burrows per $\mathrm{km}$ on the lakes studied in Ardatovsky District and that the muskrat is common here, we can assume that 17 individuals only inhabit the lakes in this area.

In 2010, we carried out a survey on the lakes at L.P. Borodin's third station in the floodplain of the Sura (Figure 8). Unfortunately, it has been revealed that the desman does not currently inhabit these lakes. Old uninhabited burrows of the desman were found on lakes Bolshoy Chadamas and Bulyk only. Traces of the vital activity of the previous desmanon these lakes

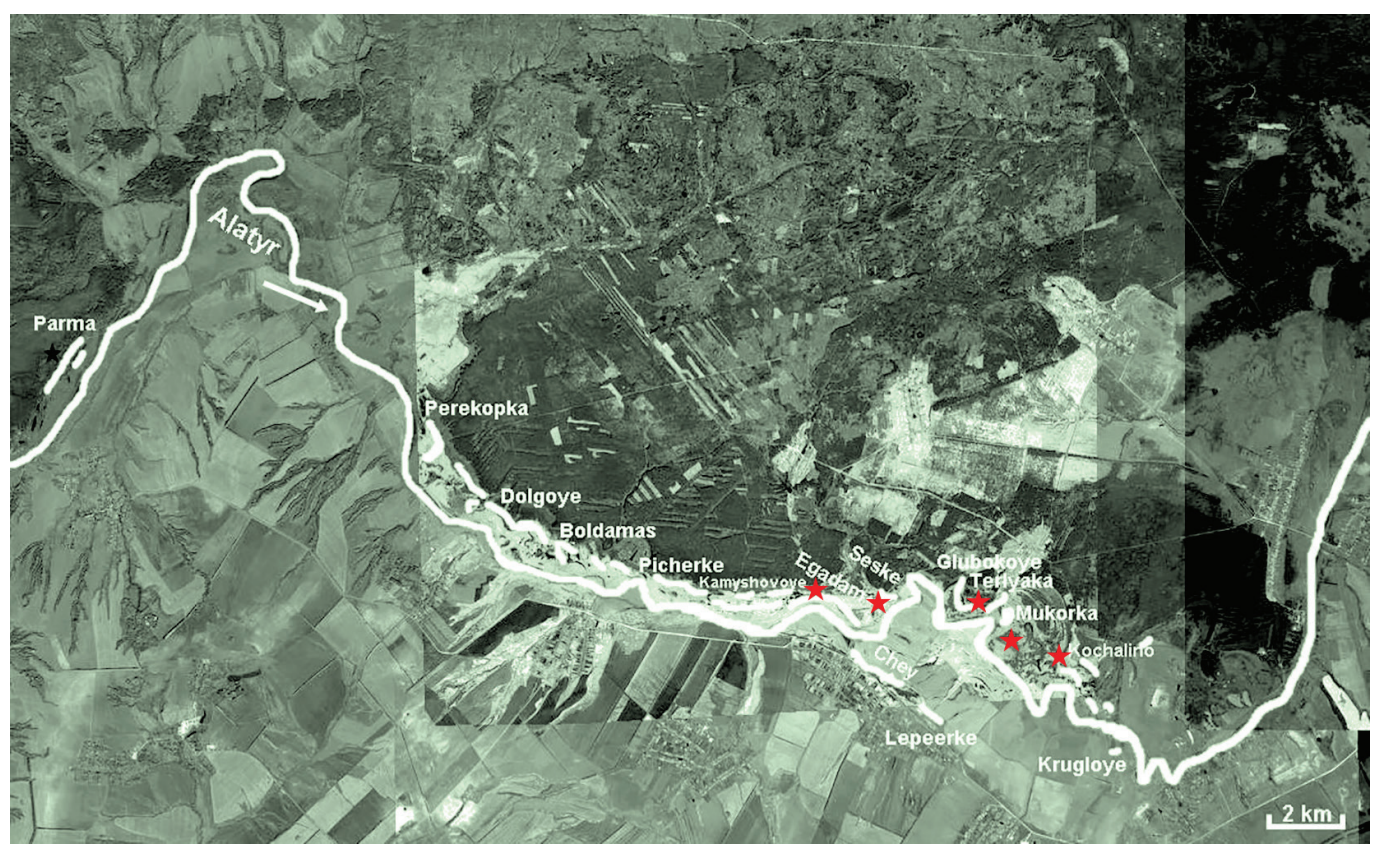

Figure 7. Records of the Russian desman in Ardatovsky District. Note: water bodies are shown in white, $\star$-desman registration points. 


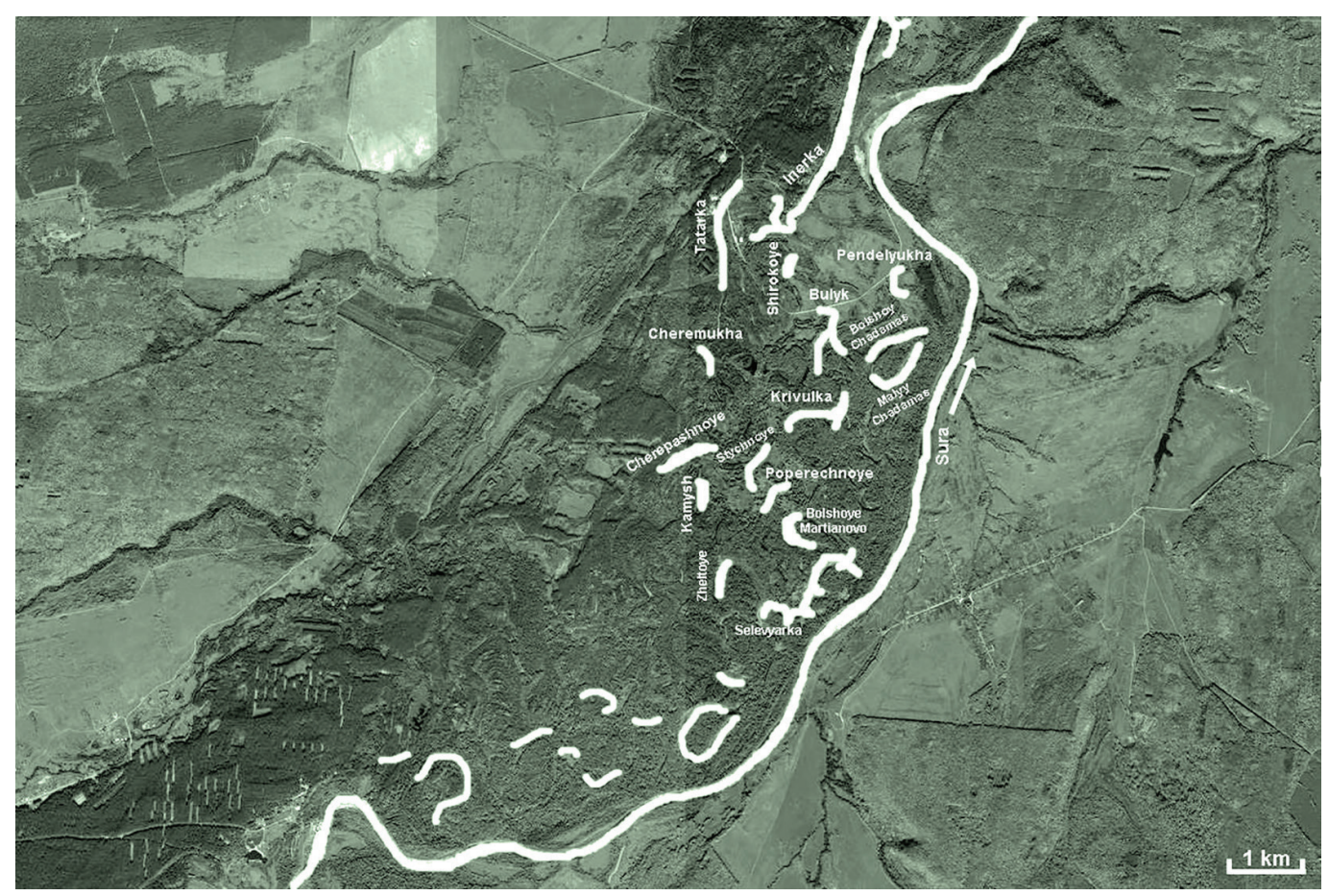

Figure 8. Records of the Russian desman in Kochkurovsky District. Note: water bodies are shown in white.

only testify to the fact that some factor contributed to the extinction of the desman. It should be noted that Lake Pendelyukha has turned into an ephemeral swamp since the studies on L.P. Borodin's stations. L.P. Borodin considered that the muskrats' settlement in desman areas was the contributing factor. He stated that the growing muskrat population leads to a dramatic decrease in the number or extinction of the desman within relationships of these two species (Borodin, 1970). It should be noted that burrows and traces of the muskrat were found in the southern part of Lake Krivulka. The situation is similar on other lakes of Prisurye.

A survey on other lakes in the Prisurye area that are not part of L.P. Borodin's station, such as Lake Selevyarka (4 km south of Lake Inerka) in Kochkurovsky District, Lake Makarikha (8 km south of Engalychevo Village) in Dubensky District, did not yield positive results with regard to the desman. Also, no results were obtained during the examination of lake margins at a biological station of the Mordovian University in Bolshebereznikovsky District.

\section{Discussion}

Thus, to date, the number of the Russian desman in Mordovia determined actually as a result of registration work is 588 individuals (Table 1). According to estimates, the total desman population is about 1,400 individuals in Mordovia (Figure 9). As we can see from the desman population dynamics diagram for the period from 1966 to 2018 , there is an increase in its population. However, a detailed study of the materials provided by us demonstrates that this is not the case. The fact is that the data for 1966 are given only according to the data of the well-known stations set up by L.P. Borodin, and this is a small territory 
in Temnikovsky and Kochkurovsky Districts. No data was available on the total species population either for these districts or for other districts. In 1982, V.S. Vechkanov presented data for several districts by extrapolating registration data obtained on areas in four districts. In fact, 149 desman individuals were registered during fieldwork in burrows on lakes. We may conclude that to date the population of the species has not increased, but the number of known desman habitats has increased due to surveys of wide territories in the districts during expeditionary studies in Mordovia. Most scientists see a tendency of a dramatic decrease in the species population in Russia (Onufrenya \& Onufrenya, 2016; Rutovskaya et al., 2017b). We can only guess the desman population in the past, but clearly, it was several times higher than now. Because during the studies performed by L.P. Borodin (1970) it was already known that desman trapping exclusively for fur production amounted to 2,493 individuals in the period from 1953 to 1956 in Mordovia. It should be noted that the largest quantity of desman skins in Mordovia was stocked in Zubovo-Polyansky, Temnikovsky and Tengushevsky Districts (71\%), that is, the Moksha basin. It is noteworthy that the situation has not changed and these areas are currently the main ones in desman conservation in the region. However, the situation is not clear in Krasnoslobodsky District where the desman is also favorably distributed throughout the reservoirs. And at the time of L.P. Borodin's work there was no information on the district at all, not only on fur production (stock), but also in general. The desman probably settled extensively in the floodplain of Krasnoslobodsky District after 1970.

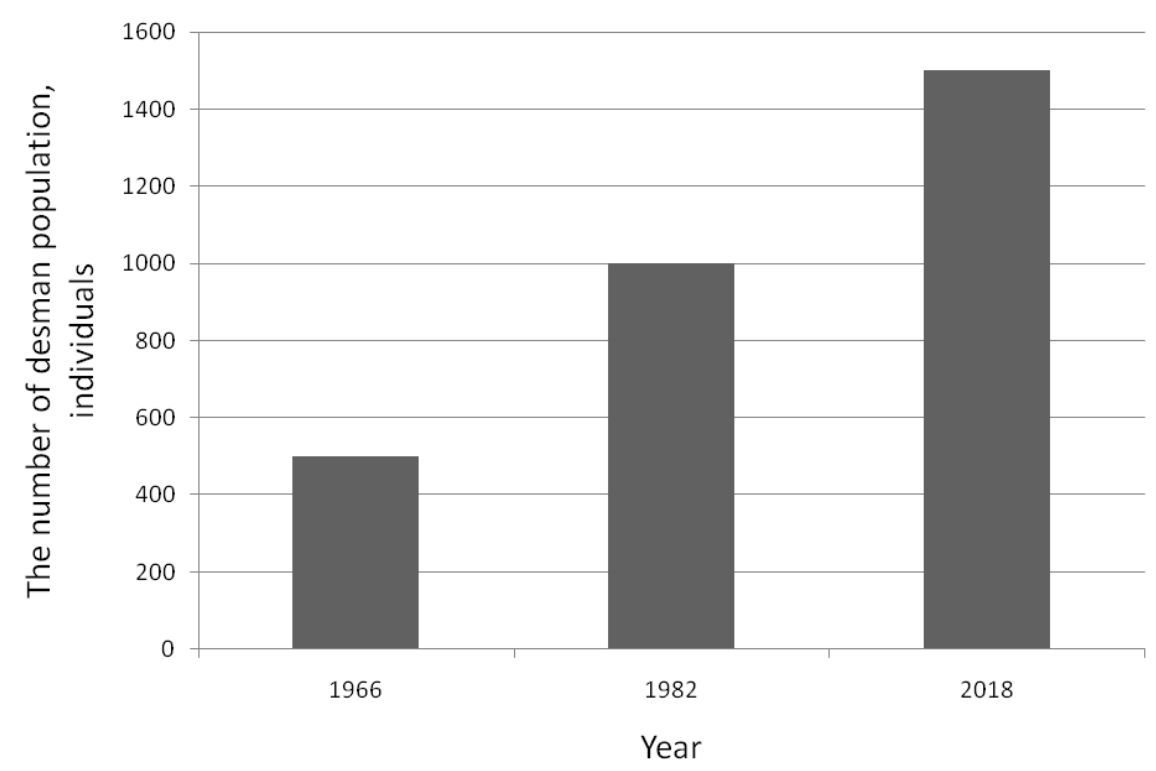

Figure 9. Changes in the number of Mordovian population of the Russian desman during the last 50 years. Data for 1966 - according to Borodin (1970). Data for 1982 - according to Vechkanov et al. (1982). Data for 2018 - according to our data for 2009-2018. 
Table 1. Relative numbers of desmans and their total reserve by results of surveys in 2009-2018.

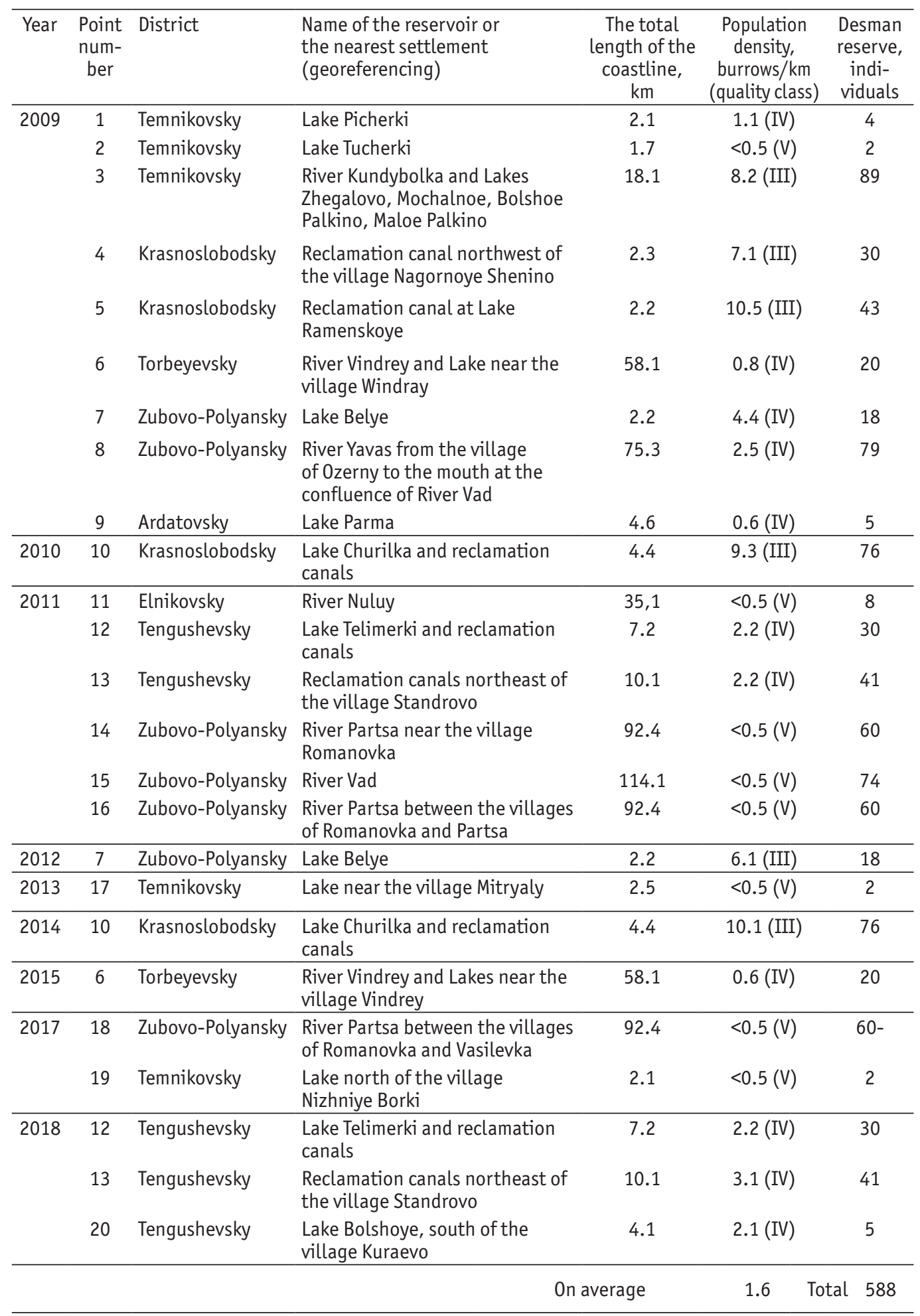


We may assume that the main desman population is concentrated on floodplain lakes and reclamation canals. About 400 animals may live on riverbeds of the Vad, Partsa, Yavas, Vindrey, Nuluy, and Kundybolka. The distribution of habitats across river basins is extremely uneven. The desman majority is in the Moksha basin (more than 1,350 individuals), and the Alatyr basin (left tributary of the Sura) has about twenty individuals.

We cannot consider the Elnikovsky floodplain of the Moksha as the key one in conservation of the desman at present, in comparison with Tengushevsky, Temnikovsky and Krasnoslobodsky floodplains. The desman population density in Torbeyevsky District is way below the density in Zubovo-Polyansky District. Therefore, we do not consider Torbeyevsky District as an important one with regard to desman conservation. The situation with the desman in Ardatovsky District is worse than in other districts where the desman was detected.

The study results demonstrate a frustrating situation with the desman in Mordovian Prisurye. However, there is reason for optimism due to the fact that the desman has persevered at present in the lower reach of the Sura according to our colleagues' registration work in 2016. According to M.V. Rutovskaya et al., (2017a) the total number of the Russian desman was more than 500 individuals in the Sura basin in Alatyrsky, Poretsky, Shumerlinsky and Yadrinsky Districts of Chuvashia and Pilnensky Districts of Nizhny Novgorod Region. The average relative density of this population was 2.4 holes at $1 \mathrm{~km}$ of the coastline. It is noteworthy that the desman was registered by researchers on the Sura in areas after meeting the Alatyr (Alatyrsky District), that is, taking into account the last registration sites in Mordovia in the floodplain of the Alatyr, the southernmost population group of the species is located in the Sura basin. This explains such a low population (about 20 individuals) and low population density. The registration point for the desman nearest to Lake Parma (Ardatovsky District) in Mordovia is Lake Staritsa south-west of the village Atrat (Alatyrsky District) in Chuvashia. The distance between registration points in a straight line is $52 \mathrm{~km}$, the distance along the riverbed is $93 \mathrm{~km}$, with $81 \mathrm{~km}$ along the Alatyr riverbed and $12 \mathrm{~km}$ along the Sura riverbed. We cannot rule out the possibility of subsequent registration of the desman at intermediate points, for example at the Alatyr mouth. A small group of individuals could not survive in isolation for several decades in the floodplain of the Alatyr on Lake Parma. The latter assumption is justified since desman habitats are scattered under Mordovian conditions in the Moksha and Alatyr basins. The distance between Lake Parma (Ardatovsky District) and the easternmost registration point in the Moksha basin (Lake Ramenskoye in Krasnoslobodsky District) is $132 \mathrm{~km}$ in a straight line.

The Russian desman is not preserved in the upper reaches of the Sura in Penza Region (Ilyin, 2003). Thus, the probability of finding the desman is extremely low up to the Alatyr mouth on the Sura. In Penza Region, the desman was recorded only in the Don basin on two steppe rivers in 2002: the Syuvernya River in Belinsky District near Lopatino Village and the Serdoba River in Maloserdobinsky District near Ogaryovka Village. There were two desman settlements per $1 \mathrm{~km}$ of the riverbed.

A somewhat better situation with the population density of the Russian desman in comparison with other neighboring regions of Mordovia is observed in Ryazan and Vladimir Region (Onufrenya \& Onufrenya, 1992, 2005; Okulova et al., 2008; Rutovskaya et al., 2015). The surveys conducted by A.S. Onufrenya and M.V. Onufrenya in 2008-2009 in the floodplain lands in the middle reaches of the Oka (Spassky and Shilovsky Districts) allow to conclude that the habitats of the desman are naturally high-quality (class I and II). The current 
state of the desman areas in most of the territory surveyed by the authors corresponds, at best, to class IV or even class V, the lowest quality class. The relative number of the desman population for the entire floodplain expansion averages 3.9 shelters per coastline $\mathrm{km}$. At the same time, this number varies from 10.9 to 6.2 shelters per coastline $\mathrm{km}$ in permanently protected or inaccessible areas, and does not exceed 1.0 in other areas. The total desman population within the borders of Spassky and Shilovsky Districts is 1,800 to 2,000 individuals, with about $80 \%$ of the total stock being within the territory of the protected area of the Oka Nature Reserve and the "Yerakhtursky" hunting reserve (Onufrenya \& Onufrenya, 2012). According to data available for Ryazan Region, the desman population is 5,960 individuals (Onufrenya \& Onufrenya, 2016), which is several times higher than the desman population $(1,400)$ in Mordovia.

According to some latest data, the Russian desman population in Russia is estimated at 8,000 to 10,000 individuals (Rutovskaya et al., 2017b); 6,000 individuals (Rutovskaya et al., 2014); 4,000 individuals (Onufrenya et al., 2011), 25,000 individuals (Khakhin, 2009). According to A.S. Onufrenya \& M.V. Onufrenya (2016), the desman population in eight regions (Oryol, Kaluga, Ryazan, Vladimir, Ivanovo, Penza, Nizhny Novgorod regions and the Republic of Mordovia) of the Oka basin is 4,110 individuals. G.V. Khakhin and A.A. Ivanov (1990) give old numbers for Mordovia - 250 individuals. Based on the data we obtained for Mordovia (plus 1,100 individuals), the number of 5,210 individuals for the Oka basin should be considered. The Moksha basin (Tengushevsky, Temnikovsky, Zubovo-Polyansky and Krasnoslobodsky Districts) should be taken into account since the desman is indigenous to the lakes and rivers here, despite the decrease in its number since L.P. Borodin's studies in Mordovia. Moreover, according to A.S. Onufrenya \& M.V. Onu- frenya (2012), the desman lives in Ryazan Region (Kadomsky and Shatsky Districts) areas bordering Mordovia, thus forming a continuous range of the species with transition to Tengushevsky and Zubovo-Polyansky Districts of the republic.

In the material presented in this article, we tried to fill in the missing information on the Russian desman population density in Mordovia, so that there would be no misconception or typing errors in the literature regarding the small number of registration points in the region. These data are important for assessing the entire range of the Russian desman. It is no coincidence that C. Nores et al. (1998) in their work on the Pyrenean desman (Galemys pyrenaicus Geoffroy, E.), whose range is many times smaller than the range of the Russian desman, report that, despite studying for several decades (Stone \& Gorman, 1985; Stone, 1987), information on the density of the population of the Pyrenean desman is extremely insufficient. This conclusion is also valid for the Russian desman, where information is collected by researchers for each individual region. According to the results obtained by foreign colleagues, the population density of the Pyrenean desman of 2.8-7.3 individuals per $\mathrm{km}$ is comparable to the population density of the Russian desman.

Acknowledgements. We are grateful to G.F. Grishutkin, G.V. Shkolov, E.A. Lobachov, S.N. Spiridonov, S.V. Susarev, V.I. Astradamov, S.G. Erofeev, E.N. Potapkin for their support in carrying out field studies.

\section{References}

Andreychev, A. 2017. Population density of the Eurasian beaver (Castor fiber L.) (Castoridae, Rodentia) in the Middle Volga of Russia. - Forestry Studies | Metsanduslikud Uurimused, 67(1), 109-115. 
Andreychev, A.V., Kuznetsov, V.A., Lapshin, A.S. Grishutkin, G.F. 2009. Preliminary materials about distribution of Russian desman (Desmana moschata L.) in the Republic of Mordovia. (Предварительные материалы по распространению русской выхухоли (Desmana moschata L.) в Республике Мордовия). Rare Animals of the Republic of Mordovia: Materials for the Red Data Book of the Republic of Mordovia for 2009. Saransk, Izdatel'stvo Mordovskogo Universiteta, 4-7. (In Russian).

Andreychev, A.V., Kuznetsov, V.A., Lapshin, A.S. 2010. On the problems and prospects of preserving the Russian desman in specially protected natural territories of Mordovia. (O проблемах и перспективах сохранения русской выхухоли на особо охраняемых природных территориях Мордовии). - Problems of the Rational use of Natural Resources and Environmental Protection: Materials of the International ScientificPractical Conference. Makhachkala, 389-390. (In Russian).

Andreychev, A.V., Kuznetsov, V.A., Lapshin, A.S. 2012. Results of inspection of possible habitats of Russian desman (Desmana moschata L.) in the western part of Mordovia. (Результаты обследования возможных местообитаний русской выхухоли (Desmana moschata L.) в западной части Мордовии). Rare Animals of the Republic of Mordovia: Materials for the Red Data Book of the Republic of Mordovia for 2011. Saransk, Izdatel'stvo Mordovskogo Universiteta, 3-5. (In Russian).

Andreychev, A.V., Lapshin, A.S., Kuznetsov, V.A., Lobachov E.A., Shkolov G.V. 2014. Information on the registration of rare mammals of the Republic of Mordovia. (Сведения о регистрации редких видов млекопитающих в Республике Мордовия). Rare Animals of the Republic of Mordovia: Materials for the Red Data Book of the Republic of Mordovia for 2014. Saransk, Izdatel'stvo Mordovskogo Universiteta, 4-5. (In Russian).

Anonymus. 1936. Desman. (Выхухоль). Moscow, Gudok. 169 pp. (In Russian).

Barabash-Nikiforov, I.I. 1959. Symbiotic links of the population of the beaver's burrow. Zoologicheskii Zhurnal, 38(5), 767-771. (In Russian with English summary).

Bogdanov, M.N. 1871. Birds and animals of the black earth strip of the Volga region and valleys of the Middle and Lower Volga. (Птицы и звери черноземной полосы Поволжья и долины Средней и Нижней Волги). Proceedings of the Society of Naturalists of the Imperial Kazan University. Kazan, V. 1. 229 pp. (In Russian).

Borodin, L.P. 1963. Russian desman. (Русская выхухоль). Saransk, Mordovian Book Publishing House. 301 pp. (In Russian).
Borodin, L.P. 1970. The desman in floodplains of the Moksha and Sura Rivers. (Выхухоль в поймах рек Мокши и Суры). Works of the Mordovian State Reserve of P.G. Smidovich. Saransk, Mordovian Book Publishing House, 5, 61-90. (In Russian).

Borodina, M.N., Borodin, L.P., Tereshkin, I.S., Shtarev, Yu.F. 1970. Mammals of the Mordovia Reserve. (Млекопитающие Мордовского заповедника). Works of the Mordovian State Reserve of P.G. Smidovich. Saransk, Mordovian Book Publishing House, 5, 5-60. (In Russian).

Chalov, R.S. 1994. Of riverbed mode of the rivers of northern Eurasia. (Русловой режим рек Северной Евразии). Moscow, Izdatelstvo Moskovskogo Universiteta. 336 pp. (In Russian).

Ilyin, V.Yu. 2003. Materials for the spread of desman (Desmana moschata L.) in the Penza region. (Материалы к распространению выхухоли (Desmana moschata L.) в Пензенской области). - Protection of flora and fauna of the Volga region and adjacent territories. Penza, 69-71. (In Russian).

Kennerley, R., Turvey, S.T. 2016. Desmana moschata. - The IUCN Red List of Threatened Species 2016: e.T6506A22321477. 11 pp. Available online: http:// dx.doi.org/10.2305/ IUCN.UK.2016-2.RLTS.T6506A22321477.en. [Downloaded 22 April 2017].

Khakhin, G.V. 2009. Russian desman in danger: dynamics of numbers and problem of protection. (Русская выхухоль в опасности: динамика численности и проблемы охраны). Moscow, Publishing House of the Biodiversity Conservation Centre. 104 pp. (In Russian).

Khakhin, G.V., Ivanov, A.A. 1990. Desman. (Выхухоль). Moscow, Agropromizdat. 191pp. (In Russian).

Kudryashov, V.S. 1976. Methodical instructions on account desmans and muskrats in inundated grounds. (Методические указания по учету выхухоли и ондатры в пойменных угодьях). Moscow, Kolos. 10 pp. (In Russian).

Kufeld, N.S. 1939. Reacclimatization of Desman in the Kuibyshev Region. (Реакклиматизация выхухоли в Куйбышевской области). - Scientific Methodological Notes of the Commission on the Reserve. Moscow. 3 pp. (In Russian).

Marchenko N.F. 2011. Methodical peculiaries of Russian desman counts. (Методические особенности учёта выхухоли русской). Povoljskii Ecological Journal, 1, 97-102. (In Russian).

Nores, C., Ojeda, F., Ruano, A., Villate, I., González, J., Cano, J.M., Garcia, E. 1998. Estimating the population density of Galemys pyrenaicus in four Spanish rivers. - Journal of Zoology, 246, 454-457. 
Okulova, N.M., Onufrenya, A.S., Onufrenya, M.V. 2008. Analysis of monitoring data on the Russian desman (Desmana moschata) in the Oka state biosphere reserve in relation to the problem of species' population decline. Russian Journal of Ecology, 39(7), 510-515.

Onufrenya, A.S., Onufrenya, M.V. 1992. Desman in Oka Reserve (Russia). - Meeting on Pyrenean Desman. Lisboa, 10-13.

Onufrenya, A.S., Onufrenya, M.V. 2005. The some aspects of biology for a Russian desman Desmana moschata in the Oka River middle course. (Некоторые аспекты биологии русской выхухоли Desmana moschata в среднем течении р. Ока). - Proceedings of the Oka Nature Biosphere Reserve, 24, 92-134. (In Russian).

Onufrenya, A.S., Onufrenya, M.V. 2008a. Distribution of Russian desman Desmana moschata in especially protected natural areas in the beginning of XXI century. (Размещение русской выхухоли Desmana moschata на особо охраняемых природных территориях в начале XXI в.). - Monitoring of Rare Species of Animals and Plants and their Habitat in the Ryazan Region. Ryazan, 33-39. (In Russian).

Onufrenya A.S., Onufrenya M.V. 2008b. Placing Russian desman Desmana moschata and an estimation of its modern number in Meshchera national park. (Размещение русской выхухоли (Desmana moschata) и оценка ее современной численности на территории национального парка «Мещера»). Monitoring of Rare Species of Animals and Plants and their Habitat in the Ryazan Region. Ryazan, 46-54. (In Russian).

Onufrenya, A.S., Onufrenya, M.V. 2012. Russian desman number and location in the Spassky and Shilovsky districts at Ryazan region in 2008-2009. (Численность и местообитания русской выхухоли в Спасском и Шиловском районах Рязанской области в 2008-2009 гг.). - Proceedings of the Oka Reserve, 27, 100-113. (In Russian).

Onufrenya, A.S., Onufrenya, M.V. 2016. Russian desman in Oka basin. (Русская выхухоль в бассейне Оки). - Proceedings of the Oka State Natural Biosphere Reserve, 37. 204 pp. (In Russian).

Onufrenya, A.S., Onufrenya, M.V., Makhotkina, K.A., Moreva, Yu.O., Rutovskaya, M.V. 2011. Current status of Russian desman population. (Современное состояние популяции русской выхухоли). - Teriofauna of Russia and adjacent territories (International Conference of the IX Congress of the Teriological Society of the Russian Academy of Sciences). Moscow. 347 pp. (In Russian).

Paramonov, A.A. 1928. Some issues of the protection of the desman. (Некоторые вопросы охраны выхухоли). - Proceedings on the Study of Nature Reserves. Moscow, 35-51. (In Russian).
Red Data Book. 2001. Red Data Book of Russian Federation (Animals). (Красная книга Российской Федерации. Животные). Moscow, Astrel. 860 pp. (In Russian).

Red Data Book. 2005. Red Data Book of Mordovia (Animals). (Красная книга Республики Мордовия. Животные). Saransk, Mordovian book publishing house. 336 pp. (In Russian).

Rutovskaya, M.V., Vanisova, EA., Zaripova, N.R., Kabychnova, A.E., Kosinsky, A.A., Makhotkina, K.A., Moreva, Yu.O., Onufrenya, A.S., Onufrenya, M.V., Popov, I.A., Sergeev, M.A. 2014. Current status of Russian desman population at territory of the historical range - results of research during last 5 years. (Современное состояние популяции русской выхухоли на территории исторического ареала - результаты исследований за последние 5 лет). Protected Areas and Objects of Vladimir region and adjacent regions. Vladimir, 86-93. (In Russian).

Rutovskaya, M.V., Vanisova, E.A., Zaripova, N.R., Kabychnova, A.E., Kosinsky, A.A., Makhotkina, K.A., Moreva, Yu.O., Onufrenya, A.S., Onufrenya, M.V., Popov, I.A., Sergeev, M.A. 2015. The flood plain of the rivers Oka and Klyazma center of the modern distribution of Russian desman. (Пойма рек Ока и Клязьма - центр современного распространения русской выхухоли). - Proceedings of the Oka State Natural Biosphere Reserve, 34, 125-131. (In Russian).

Rutovskaya, M.V., Glushenkov, O.V., Akimov, S.I., Bereznoi, M.A, Voronin, E.A., Zaripova, N.R., Kuzmina, M.S., Popov, I.A., Soboleva, A.S., Sokolova, M.N. 2017a. The population status of the Russian desman in the

lower reaches of the river Sura. (Состояние популяции русской выхухоли в пойме нижнего течения реки Сура). - Scientific Works of the National Prisursky Nature Reserve, 32, 179-188. (In Russian).

Rutovskaya, M.V., Onufrenya, M.V., Onufrenya, A.S. 2017b. Russian Desman (Desmana moschata: Talpidae) at the edge of disappearance. Nature Conservation Research (Zapovednaya Nauka), 2 (1), 100-112.

Shidlovskaya, N.K. 2018. Factors determining the dynamics of the desman population in the Mordovia State Natural Reserve and adjacent lands based on the results of the survey in 1961. (Факторы, определяющие динамику численности выхухоли в Мордовском государственном природном заповеднике и смежных угодьях по результатам учета в 1961 году). - Proceedings of the Mordovia State Nature Reserve, 21, 16-26. (In Russian).

Sokolov, A.A. 1964. Hydrography of the USSR. (Гидрография СССР). Leningrad, Gidrometeoizdat. 468 pp. (In Russian).

Sokolovsky, D.A. 1968. River drain. (Речной сток). Leningrad, Gidrometeoizdat. 539 pp. (In Russian). 
Stone, R.D. 1987. The social ecology of the Pyrenean desman (Galemys pyrenaicus) (Insectivora: Talpidae), as revealed by radiotelemetry. Journal of Zoology, 212, 117-129.

Stone, R.D., Gorman, M.L. 1985. Social organization of the European mole (Talpa europaea) and the Pyrinean desman (Galemys pyrenaicus). Mammal Review, 15(1), 35-42.

Tereshkin, I.S. 1971. Desman and muskrat in the floodplain of Sura. (Выхухоль и ондатра в пойме Суры). - Proceedings of the first scientific conference on the problem of fauna, ecology, biocenology and animal welfare of the Prisurye. Saransk, 104-106. (In Russian).

Report. 1982. Report on the transfer and implementation of scientific and technical achievements on the topic: Study of the current number of desman and recommendations on the choice of places for the introduction of the species and the organization of specialized reserves in the territory of the Mordovian ASSR as part of the economic agreement. (Исследование современной численности выхухоли и рекомендации по выбору мест для интродукции вида и организации специализированных заказников на территории Мордовской АССР в рамках хозяйственного договора). Performers: Vechkanov, V.S., Smirnov, V.M., Ananyev, A.A., Shevorakov, A.V., Matyaev, V.M., Tomilov, Yu.A., Grishutkin, G.F., Mikova, S.A. № 1-82, 60 pp. (In Russian).
Report. 1983. Report on the topic: Experience in the introduction of the desman in floodplain water bodies in connection with its semicaptive content within the framework of the economic agreement. (Опыт по вселению выхухоли в пойменные водоемы в связи c еe полувольерным содержанием в рамках хозяйственного договора). Performers: Vechkanov, V.S., Smirnov, V.M., Tomilov, Yu.A., Grishutkin, G.F., Mikova, S.A., Shevorakov, A.V., Ilyin, V.G., Matyaev, V.M. № 34-83, 36 pp. (In Russian).

Water resources. 1999. Water resources of Republic Mordovia and geo-ecological problems of their development. (Водные ресурсы Республики Мордовия и геоэкологические проблемы их освоения). Performers: A.A. Yamashkin, V.N. Safonov, A.M. Shutov and others. Saransk, 1-188. (In Russian).

Yevstigneyev, V.M. 1990. River drain and hydrological calculations. (Речной сток и гидрологические расчеты). Moscow, Izdatelstvo Moskovskogo Universiteta. 304 pp. (In Russian).

Zhitkov, B.M.,1898. Materials on the mammalfauna of Simbirsk province. (Материалы по фауне млекопитающих Симбирской губернии). - Diary of the Zoological Department of the Society of Amateurs of Natural Science, Anthropology and Ethnography and Zoology of the Museum, 2(8), 1-27. (In Russian). 